\title{
Correction to: Geochemical and isotope evidence for mantle-derived source rock of high-K calc-alkaline I-type granites, Pernambuco-Alagoas Domain, northeastern Brazil
}

\author{
Thyego R. Silva ${ }^{1} \cdot$ Valderez P. Ferreira $^{1} \cdot$ Mariucha Maria C. Lima ${ }^{1} \cdot$ Alcides N. Sial $^{1}$
}

Published online: 15 June 2021

(c) Geologische Vereinigung e.V. (GV) 2021

\section{Correction to:}

International Journal of Earth Sciences

The correct Fig. 14 is given below:

(2019) 108:1095-1120

https://doi.org/10.1007/s00531-019-01696-9

The authors regret that two very unpleasant mistakes remained uncorrected. Unfortunately, Fig. 14 shows vectors pointing in the wrong direction.
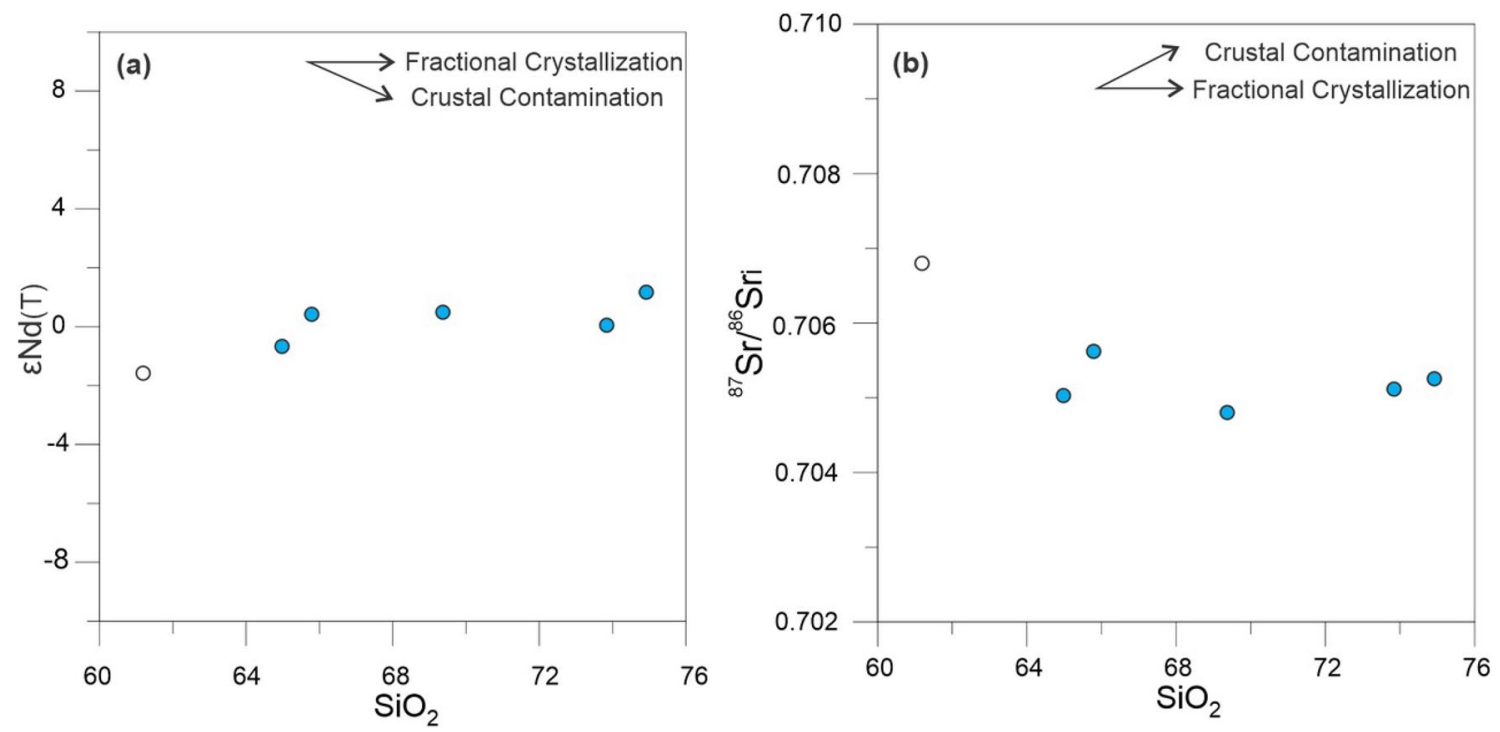

Fig. 14 a $\varepsilon \mathrm{Nd}(\mathrm{t})$ and $\mathbf{b}^{87} \mathrm{Sr}^{86}{ }^{86} r_{\mathrm{i}}$ vs. whole-rock $\mathrm{SiO}_{2}$ for the studied granitic rocks. Symbols as in Fig. 4 from Silva et al. (2019)

The original article can be found online at https://doi.org/10.1007/ s00531-019-01696-9.

Thyego R. Silva

rthyego@yahoo.com

1 NEG-LABISE, Department of Geology, Federal University of Pernambuco, Av. da Arquitetura s/n, Cidade Universitária, Recife, PE 50740-550, Brazil

\section{Reference}

Silva TR, Ferreira VP, Lima MMC, Sial AN (2019) Geochemical and isotope evidence for mantle-derived source rock of high-K calcalkaline I-type granites, Pernambuco-Alagoas Domain, northeastern Brazil. Int J Earth Sci 108:1095-1120. https://doi.org/10. 1007/s00531-019-01696-9 